\title{
Who Do They Think They Are: Making Sense of Self in Residential Care, Foster care, and Adoption
}

\begin{abstract}
This article explores how the type of placement in children's social care influences identity formation and contact with the birth family. It draws on 40 life history interviews with Romanian-born, care experienced young people who entered adulthood from different types of placement: 16 from residential care, eight from foster care, seven from domestic adoption and nine from intercountry adoption. The article contributes to an understanding of how residential care, foster care, domestic adoption and intercountry adoption affect identity formation and contact with the birth family from the perspectives of those who lived them, the challenges they encountered and the strategies they adopted to make sense of who they were during adolescence and transition to adulthood. The findings suggest that all the research participants had met or wanted to meet their birth families, and that stigmatisation occurred in all types of placement. The type of placement they were in influenced the support or the challenges they faced when they wanted to gain knowledge of their birth families and the circumstances in which they met their birth family. In some cases, their intention to search for the birth family led to tensions or conflict between them and their adoptive or foster carers. However, this study suggests that knowledge of, and contact with their birth family did not modify the quality of the children's relationship with them (foster carers or adoptive parents). It also suggests that when raised by carers other than their birth parents, children allocate parental roles to carers or other significant adults and that challenges related to identity formation in adolescence differ between residential care, foster care and adoption.
\end{abstract}

Keywords: identity; children in care; residential care; foster care; adoption; Romania. 


\section{Introduction}

Weeks after the adoption of the UN Convention on the Rights of the Child (1989) in New York and the fall of the Berlin Wall, Romania made the headlines in the international media that reported on the squalid condition in the country 's orphanages. This led to unprecedented humanitarian aid, external pressure on the government and persistent demand from Western families and individuals to adopt Romanian children (Kligman, 1998). As a result, conditions in institutions were somewhat improved in the 1990s and the number of intercountry adoptions increased to a rate that caused concern to international organisations such as the European Union and the United Nations (Groza, 2014). As Dickens (2002, 76) put it 'Romania became almost synonymous with intercountry adoption'. At the same time, Romania was one of the first countries to ratify the UN Convention on the Rights of the Child (Bejenaru \& Tucker, 2017) and became a regional model undertaking several reforms of its child protection system (Gavrilovici, 2009). Prior to its accession to the European Union (2007), Romania was required to reform its child protection system. This entailed improving conditions and reducing the number of children in residential care, introducing foster care, and promoting domestic adoption. Intercountry adoption was restricted and allowed only in exceptional circumstances (Iusmen, 2013; Jerre, 2005). Romania's children in care born around 1990 became adults when Romania joined the European Union (2007). The policy changes throughout this period affected their care trajectories. Their life histories provide rich accounts of how such diverse types of placements (residential care, foster care, domestic adoption and intercountry adoption) impact on the young people's sense of self. 


\section{Identity Formation and Children in Care}

The importance of children's identity is enshrined in Articles seven and eight of the UN Convention on the Rights of the Child, according to which every child has the right to a name, nationality, the right to know his or her parents and to preserve these inherent elements of identity. The Convention proposes as tenets of identity - name, family, nationality - that treat children as rights holders protecting them against human trafficking. Moreover, Article 20c regarding care, specifies that when children are taken into care 'due regard shall be paid to the desirability of continuity in a child's upbringing and to the child's ethnic, religious, cultural and linguistic background' (UN General Assembly, 1989) emphasising the need to maintain continuity, one of the key elements in the construction of identity (Breakwell, 1986). Moreover, articles 2 (on non-discrimination), 3 (on the best interests of the child) and 12 (on the right to be heard) contribute arguably to children's distinctiveness and self-esteem - the other key features of identity (Breakwell, 1986) - by treating them as unique and as humans who must to be heard and whose best interest must be paramount when making decisions that concern them.

Identity is key to human development for the way in which humans perceive themselves and how they interact with others. It is closely connected to one's agency, belonging, self-esteem (Baumeister, 1986), autonomy (Erikson, 1994), and it contributes to young people's resilience and wellbeing (Sen, 2006; Sharma \& Sharma, 2010). These concepts are often used in research with looked after children and positive identity is an important protective factor for young people to succeed (Noble-Carr et al., 2014), with some studies taking an interpretative approach to study identity in different types of placement (Ferguson, 2016; Winter \& Cohen, 2005) including adoption (Grotevant \& Von Korff, 2012) where the permanent change of the child's legal identity is a key element. 
The importance of continuity and stability has been explored in studies that explored the long term impact of foster care (Andersson, 2009; Rowe, Cain, Hundleby, \& Keanne, 1984; Schofield, Thoburn, Howell, \& Dickens, 2007; Schofield et al., 2012; Sinclair, Baker, Lee, \& Gibbs, 2007) or pathways to adulthood from foster care (Courtney et al., 2016; Stein, Emily, \& Munro, 2008) and others that explore the role and impact of residential care on young people (Ainsworth \& Thoburn, 2014; Schofield, Larsson, \& Ward, 2016; Whittaker et al., 2016). Several studies on adoption have explored belonging, permanency and outcomes in adoption (Biehal et al., 2010; Neil, Beek, \& Ward, 2013; Selwyn \& Wijedasa, 2014; Wijedasa \& Selwyn, 2011). Other studies have undertaken comparison between foster care and adoption (Biehal et al., 2010) or between foster care, residential care and adoption (McSherry, Fargas Malet, \& Weatherall, 2016; Triseliotis \& Hill, 1990). Rutter's English Romanian Adoptees longitudinal study (Rutter et al., 2007) studied the impact of adversity at an early age on children's subsequent development for Romanian adoptees in the early 1990s.

For the purpose of this study, we draw on Breakwell's (1986) concept of 'threatened identities', and regard a child's move into care as an identity threat that can affect a child's continuity, distinctiveness and self-esteem. When children enter the care system, many children lose their kin identity, receive a collective identity (children in care) and are identified by different labels given by professionals (reflecting the legal jargon) or by society (often reflecting stereotypes about them). The principles of continuity, distinctiveness and self-esteem are replaced with discontinuity in their relationships and in their environment, identification and stigmatisation (Ferguson, 2016). Findings in this study point out the additional challenges that being in care add to identity formation, confirming other studies such as Kools (1997) or Goffman's theory on stigma according to which the stigmatised are identified as bad or weak or dangerous (Goffman, 1990). 
The type and the quality of a placement will impact on how much young people can explore who they are, their identity struggles and go through the moratorium phase in which new roles are tried (Marcia, 1980). For example, the type of placement determines who are the children's gatekeepers of contact with their birth families and will influence their social relations and self-esteem, both key elements in the process of forming their personal and social identity. The extent to which their carers or substitute parents allows them to explore knowledge about their genetic identity impacts on their wellbeing (Król et al., 2018; Triseliotis, 1973).

In adoption and in foster care, children's contact with their birth family can be mediated or obstructed by foster carers or adoptive parents if they consider that that would not serve the children's interest regardless of the children's wishes (Boyle, 2015). In the case of adoption, children often have their names changed and, in the case of intercountry adoption, the change of country usually entails a change of language, social norms, and possibly a change in terms of support, parental expectations and support in transition to adulthood that comply with wider parental norms or attitudes towards adoption in the receiving country.

Although residential care can, by its nature, facilitate contact (not least because family members would know where the child lives), it also promotes group identity and solidarity (Appiah, 2005) more prominently to the detriment of personal identity and distinctiveness. The social image of children in residential care is associated with that of their group and their social access can be facilitated or obstructed based on stereotypes that others hold in relation to that group (Goffman, 1990; Licata et al., 2012). 


\section{The Current Study: sampling, method and data analysis}

Romania became a case study in the 1990s for the adverse conditions in which children in residential care had been living. The reform of its child protection system in the late 1990s and early 2000s offered a unique research opportunity in understanding the impact of different types of placements from the perspective of young adults who experienced them during their childhood. The 40 research participants taking part in this study were born around 1990 and were between 20-31 years old at the time of the interview. Their mean age was 24.92 and 18 of them were females and 22 males. Most research participants (30 out of 40) entered care by the age of four and almost half (17 out of 40) experienced at least two types of placement throughout childhood. Over a third of them (16) had residential care (large institutions or small group homes) as their main care experience, eight long term foster care and 16 were adoptees (nine international adoptees and seven domestic adoptees) as shown in Table 1 . The study had university ethics approval. 
Table 1: Characteristics of the sample

\begin{tabular}{|c|c|c|c|c|}
\hline $\begin{array}{l}\text { Primary }{ }^{1} \text { Type of } \\
\text { Placement }\end{array}$ & Residential Care & Foster Care & $\begin{array}{l}\text { Domestic } \\
\text { Adoption }\end{array}$ & $\begin{array}{l}\text { Intercountry } \\
\text { Adoption }\end{array}$ \\
\hline $\begin{array}{l}\text { Number of } \\
\text { Research } \\
\text { Participants }\end{array}$ & 16 & 8 & 7 & 9 \\
\hline $\begin{array}{l}\text { Gender of } \\
\text { Research } \\
\text { Participants }\end{array}$ & $\begin{array}{l}7 \text { Female } \\
9 \text { Male }\end{array}$ & $\begin{array}{l}4 \text { Female } \\
4 \text { Male }\end{array}$ & $\begin{array}{l}4 \text { Female } \\
3 \text { Male }\end{array}$ & $\begin{array}{l}5 \text { Female } \\
4 \text { Male }\end{array}$ \\
\hline $\begin{array}{l}\text { Age range at the } \\
\text { time of the } \\
\text { interview }\end{array}$ & $24-31$ & $20-27$ & $20-31$ & $22-31$ \\
\hline $\begin{array}{l}\text { Age range for } \\
\text { entering this type } \\
\text { of placement }\end{array}$ & $0-12$ & $7-14$ & $0-7$ & $0-17$ \\
\hline $\begin{array}{l}\text { Age range for } \\
\text { entering care } \\
\text { (any type of } \\
\text { placement) }\end{array}$ & $0-12$ & $0-11$ & $0-7$ & $0-4$ \\
\hline
\end{tabular}

${ }^{1}$ Twenty three research participants experienced more than one type of placement

This study draws on 40 life history interviews of Romanian-born, care experienced people most of them in their 20s. The interviews were semi-structured and they were all conducted by the first author. The research participants were asked to reflect on their childhood, their transition to adulthood and their current lives. The interviews were conducted in the interviewees' first language. Most interviews were conducted in Romanian, the native language of both the first author and the interviewees. For those adopted in English speaking countries (USA, United Kingdom and Ireland), the interviews were conducted in English. The interviews with the research participants adopted in Italy were conducted in Romanian as one was still fluent in Romanian and the other research participant chose a person she trusted as interpreter. With the exception of three interviews conducted on Skype, the interviews 
were conducted face to face, at locations agreed and preferred by the research participants that could provide a mix of anonymity, privacy and comfort. In a few cases, they were conducted at the research participant's home or a trusted friend's home.

The Skype interviews were conducted by the first author with research participants who live in different parts of the United States. All three research participants were recruited through a social media group set up by Romanian born intercountry adoptees. The first author engaged in preliminary talks with those who expressed interest in being interviewed to ensure that informed consent was obtained prior to undertaking the interview. The interviews were synchronous (James \& Busher, 2012). In these cases, the transcripts were then sent to the research participants to make sure that they reflected what they said given that the connection was poor in a couple of instances and two interviews were briefly interrupted. The researcher's declared presence on the online group providing expert advice on how they could connect with their families contributed to building rapport with the research participants.

Given the lack of records for such hard to reach populations and the difficulty in accessing personal data, this was a mix of purposive and snowball sampling that drew on a variety of sources: social services, NGOs, social media and personal contacts of the first author.

The interviews were transcribed verbatim and analysed using NVivo. All data was translated in English following a back translation exercise that the researcher undertook with another academic who is proficient in Romanian. An emerging thematic coding approach (Miles, Huberman, \& Saldana, 2014) was employed. 
The main focus of the analysis was the care experience of the young people. The 'care' theme included sub-codes for each type of placement (residential care, foster care, domestic adoption, intercountry adoption) as well specific sub-codes for 'entering care/ change of placement', 'abuse', 'belonging', 'child consultation' and 'agency'. The other themes were 'knowledge of/contact with the birth family', 'self and others' ('self-perception', 'significant others', 'stigmatisation', 'discrimination') and 'life stages' ('life before care', 'entering care or changing placement experience', 'adolescence', 'transition to adulthood' and 'current life'). This article conveys the themes that are related to 'adolescence', 'contact with the birth family' and 'self and others'.

Life history interviews allowed the analysis of agency and identity, their evolvement in time, emphasising their fluidity (Georgakopoulou, 2006). They enabled an understanding of the construction of 'the self' and young people's agency (Bamberg, 2015), contributing to a wider narrative on the various types of placement from an insider perspective.

By analysing data on their care experience, knowledge of the birth family and school experience, this article draws on Breakewell's threatened identity theory and Goffman's theory on stigma to explore how different types of placement impact on care-experienced young people's knowledge of their birth family and on their identity formation (continuity, distinctiveness and self-esteem)?

\subsection{Limitations of the Study}

The findings are based on the accounts of 40 young people born in Romania in the late 1980s or early 1990s and who grew up in residential care, foster care or in domestic or intercountry adoption. It is based on the analyses of their views and does not include the views of their 
parents or carers. Although the findings make an important contribution to understanding the impact of different types of placement from the young people's perspective, the findings cannot be generalised.

\section{Findings - Knowledge of Birth Family and Identity in Different Types of Placement}

Breakwell (1986) set out four strategies for dealing with threatened identities: isolation (minimising the threat by isolating themselves from others; employing self-disclosure in specific circumstances), negativism (acting against the identity threat), passing (gaining access to a group by camouflaging's one's group origin) and compliance as a strategy when other strategies fail.

Several interviewees reported that disclosure supported them in making friends among peers, something they had avoided before in order to escape the threatening position of stigma. This finding supports Goffman's claim that when people become closer, stereotyping is replaced by sympathy, understanding and a realistic assessment of the person. Several interviewees mentioned establishing meaningful friendship relationships during teenage years, a stage that is classified as the ideological state by Erikson when they start to form social relationship independently from their parents (Coleman, 2011).

Findings suggest that both the quality and the type of placement had an influence on the circumstances in which they could gain knowledge and contact with their birth families and on the way they were able to manage stigma. This section presents the specificities of contact 
and the strategies young people used to manage stigma and identification in each type of placement.

This section reports on strategies adopted by the young people during their adolescence to manage their care status. It draws on data in the 'adolescence', 'school experience' and 'contact with the birth family' codes. The empirical evidence suggests two main areas of interest for the young people during their teenage years: their knowledge of their birth family and managing their status in relation to their peers in school. All the research participants in this study either knew or expressed an interest in knowing their birth families, confirming other research (Fargas \& Mc Sherry, 2018; Triseliotis \& Hill, 1990; Triseliotis, 1973). Most research participants spoke about stigmatisation related to their care status, regardless of the type of placement they were in.

\subsection{Making Sense of Self in Foster and Residential Care}

The young people who participated in this study experienced care in Romania in the 1990s and early 2000. During that time, changes in placement in residential were mostly limited to statutory reasons (at age 7) or to place children in long term foster care or in a small group home. Placements in foster care were planned as long term but in three cases they terminated during teenage years at the young people's request.

Those of them placed in public care (foster or residential care) were able to access information about their birth family at an earlier age compared to those in adoption and most of them were in contact with their families (parents, siblings or grand-parents) at the time of 
the interview. For those placed in foster care, contact with the birth family depended on the willingness of the foster carers to support it. Unlike the young people who were adopted internationally, those who grew up in residential or foster care maintained their names, their language, and their citizenship and grew up in the same geographical area as their birth families.

Many participants spoke about their school experiences recounting feeling different, confused or out of place, supporting Goffman's conceptualization of the stigmatised that they do not feel that any other groups they belong to are their real ones. The ways in which several of them described being bullied in school or suspected of antisocial behaviour (stealing, begging) corroborates Jenkins' (2008) hypothesis that '[i]n identification, the collective and the individual occupy the same space'. Very few interviewees with experience in residential care reported having friends amongst the 'normal' population of children during their childhood. Reportedly, stigmatisation did not occur in schools located close to residential care institutions where children in care were in large numbers. During adolescence, several young people developed their passing strategies to hide their care status from their peers and in one case the young person in foster care continued to hide his care status during adulthood.

\subsubsection{Residential Care}

Out of 40 research participants, 16 were in long term residential care and their transition to adulthood was from institutions (ten) or small group homes (six). With one exception, all of them had some knowledge of their families and all except two had met their parents at least once. Those who were placed in residential care at school age or later, maintained some contact with their birth parents or siblings whereas only one of those placed at an early age, mentioned any visit from birth family members. For the others, the social services initiated 
contact with the birth families. In some cases, that was triggered by the children's expressed interest in getting to know their family members. Two female research participants recalled that they were sent home during one summer holiday at age 10 and 12 respectively and they regarded these temporary stays among the most difficult times in their life due to abuse and neglect in one case and tensions with her mother and stepsister in the other case.

In one case, the research participant asked her social worker to find her mother from whom she wanted to find out why she had not consented to her adoption. In her case, the one contact with her mother was not followed by others, suggesting that the purpose of contact was closure rather than to maintain contact.

Four of the research participants in this cluster were placed in residential care with at least one other sibling. In these cases, the narratives suggest that when siblings were placed together, they supported and protected each other. In one case, the brother was able to protect his sister from bullying although he was one year younger. In the cases where siblings stayed at home, the sibling relationships were not maintained during childhood but many of them reconnected during adolescence or early adulthood. In at least two cases, residential care was described as having had a positive role in their life by providing them with a good education that their (older) siblings who had stayed at home had not achieved. One research participant recalled that her brothers call her 'the normal one' because she went to school and she had a job. When separated from their siblings, contact was lost in some cases, maintained in others, and convoluted in at least two cases.

Many of the research participants in residential care stayed in the same institution throughout their school years. This allowed them to form stable relationships with some of the staff 
members as well as the other young people. During interviews they referred to specific staff members as 'mother' or 'social mother'. This finding is corroborated by other research which has shown that children in residential care can establish strong emotional bonds to staff members (Novelle \& Gonyea, 2016). One of them spoke about a teacher he was attached to as 'first mother', the mother of a school friend 'second mother' and staff member who fostered him informally as 'social mother'. However, one interviewee who entered care at age 12 , made a point of refusing to call staff members 'mother' (an expectation in her small group home) since she had her mother with whom she was in contact. At the time of the interview, most of the research participants in this cluster were in contact with their parents and/or their siblings.

By the time they reached adolescence most research participants in this cluster already knew their birth families and why they were in care. A key concern for the research participants in this cluster during adolescence was the importance of managing the information about their care status in secondary school or in relation to others outside the care system. Several of them made efforts to conceal their care status among peers and described states of anger or anxiety in circumstances where they had to admit it. This example illustrated the intensity of the feelings around this:

'[In high school] I had problems with my teachers. I mean there I really felt discriminated because I was the only one [in care] in my class... During the first week of [high] school I talked to my tutor .... I remember that I waited for her outside my class .... I waited for about 10 minutes. The tension was increasing as I didn't feel as free as I did in primary school where I didn't have to hide the fact that I came from the child protection system. There I was the only one ... I was at an age when it mattered for me that people didn't know certain things about me because by and large people didn't have a good opinion about those from the protection system. They would call us 'nefamilisti' [people without a family], caminari [those from the children's home] or other names which... I said to her that I'd prefer that this be treated as confidential and she assured me that it would be confidential. ... I remember that I was very careful in order not to raise 
questions, so I didn't have to lie more and more, I avoided bringing up certain subjects. After school, in conversations I'd say I go to my place, I avoided mentioning parents in conversations ... I would avoid this subject completely and I was very careful. I did this for three years, not knowing that they already knew my situation. I told a few colleagues when I was in year 11. Just a few of them knew at some point but I thought most of them didn't know. And someone told me when I was in year 11: "I know since year nine, since the first day, all the class knows from the teacher".' (Male research participant, 28)

Sharing their care status with a few peers, in a strategic way over time is reflected in several of the narratives in the study, confirming Breakwell's (1986) claim that self-disclosure to a small number of people can be part of isolation, a coping strategy for threatened identities. As Goffman (1990) suggests, the stigmatised make efforts to control the information about them. Public image and hiding their care status was important to them. Apart from being concerned with their public image, several male research participants took part time jobs or started lucrative activities (haircuts, IT, shop manager) that would help them earn money they would use to consolidate their social capital. With the money they earned, they could participate in their peers' social life or gain a status in relation to their peers from inside and outside the institution. As regards intimate life, none of those who were placed in care at birth or in the first months after birth (seven out of 16 in this group) mentioned any romantic relationships they had been involved in at the time of the interview. This was not the case for those who entered care later (age four and over). This finding is in line with other studies in the field (Coll et al., 2010; Orlofsky, Marcia, \& Lesser, 1973).

The narratives of male and female participants differ as do those who entered care earlier or later. Male participants who were placed in care at an early age and were not in contact with their birth family mentioned feelings of loneliness, depression or anxiety about their future. One research participant said that at age 16, he stopped celebrating his birthday and as he approached his $18^{\text {th }}$ anniversary he felt depressed and spent the day getting drunk with a 
friend away from the others. They had some support from the child protection services in getting jobs, mostly underpaid and looked for affordable accommodation, in a few cases supported by their employers.

In contrast, none of the female participants' teenage trajectories mention work opportunities. Their narratives focused on significant adults (care workers, sports coach, and religious leader) who provided them with mentoring or other types of support personal support (practitioners, employers, work peers). One research participant who entered care at age 12 decided to leave care early and experienced a more sinuous trajectory with risk of abusive or convenience relationships or homelessness but she also found a mentor in her locality who provided her with the support she needed. At the same time, two of those who entered care later and had a positive care experience were in long term relationships and having or expecting children at the time of the interview.

Findings in this cluster highlight the complexity of residential care as narratives suggest that both agency and victimhood were developed within the residential care system. The stories of agency appeared mainly in those narratives in which the research participants entered care at age five or later, entered care with siblings, or had preferential treatment from members of staff. In one case, the research participant who grew up in care from birth described violence from older peers in her childhood as well as an episode during her teenage years when she became violent towards younger children but on reflection had decided to stop. The stories of victimhood were described by those who entered care early, since birth until age four) who had not recalled any contact with their birth families during their early childhood. 


\subsubsection{Foster Care}

Out of the 40 research participants, 12 had some experience in foster care, eight of them having spent their adolescence (or some of it) in foster care. Three of them asked for change of placement during teenage years and went into residential care (one), kinship care (one) and guardianship (one). One went into foster care from her birth family (at age seven) and the others from residential care, as foster care was introduced in the child protection system while they were in residential care.

At the time of the interview, all of the research participants with foster care experience except one knew at least their mother's identity and were, or had been in contact with their parents and/or siblings.

In three of the eight cases, contact with elder siblings (two cases) and with birth mother (one case) took place in a private and informal manner with support from the foster carer and not necessarily with the involvement of the social services. These placements were stable and were described in positive terms, suggesting the importance of the privacy of family life even in the regulated domain of children's social care. In these circumstances, the research participants were able to develop an understanding of who they were without feeling a risk of placement breakdown. These narratives suggest that local geographies with their local informal networks contributed to the child's sense of identity. One research participant met one of her elder siblings at a fair who then started to visit her at her foster placement:

'You know what it's like. The foster carer doesn't really like it having visits at home. Even now, you go to the [child] protection [service], you do your contact hour ... there. But mummy [name of the foster carer] being very kind ... she accepted. Because they understood that it wasn't possible like that. And then I 
know that mummy [foster carer] had an inspection from child protection. And the ladies from child protection knew. And they told her off once because she had not written a note when they came. Mummy told them 'did you tell me to, you didn't, how could I know?' And since then she started to write to them. There weren't any problems... Well, it was only my brother and only later daddy came.' (Female research participant, 20)

At the same time, when the young person's desire to know their birth family was not supported by the foster carers, this led to conflict and later to placement breakdown. Narratives also suggest that contact was not something that was deliberately sought by the social services but that it was initiated either at the request of the young person during teenage years or it stemmed from rather fortuitous circumstances, emphasising the role of space and community in children's care. In one case, the research participant was taken by her social worker to meet her mother as she was coming of age with an intention to go and live with the mother she had been estranged from an early age, without subsequent contact. The narratives of reunion from the foster care cluster reiterate children and young people's need to have knowledge about their birth families.

Similar to research participants who grew up in residential care, most young people with foster care experience chose to hide their care status from their school peers or others who were not aware of it. This was somewhat facilitated by the fact that they were in families and a few mentioned the strategies they created to justify the difference in name when asked.

Those placements where they did not feel encouraged to speak about or supported to meet their parents or other relatives were also placements where they described feelings of shame or isolation. The fact that the research participants felt they had a say in with whom they would have contact and their carers supported them to achieve this, contributed not only to their identity formation but also to their agency. 
Most of them referred to their foster carers as mother and father regardless of the quality of the relationships with their carers. One research participant placed in foster care (from residential care) at age 11, explained:

'Even when I was adopted, my mother who raised me was told ... that we shouldn't call them 'mother' and 'father'. But when they [the child protection staff] say that they do not think that we need these two words, you can't otherwise when you are in a family... But I can tell you why they were told so, I am not taking anyone's side, for us not to get attached to them, or them not to get attached to us. But that was not possible, I'm telling you, that was not possible. When I saw her for the first time, I called her 'mother'. I was pretty old when I was given [placed in foster care]' (Female research participants, 27)

In the foster care cluster who remained in foster care until 18 (three male and three female research participants), the young men stayed with their foster carers beyond age 18 (one started a full time job and the other two went to higher education) whereas the young women all left at 18 although the average age of marriage for women in Romania in 2016 was 29.4 (Agerpres, 2019): one entered a convenience marriage, one had to leave when she became pregnant and one married her boyfriend. This suggests a patriarchal approach towards young people in care. As in the residential care group, those who entered care at birth or soon after did not speak of any romantic relationships. It is important to note that their first placements had been in residential and not in foster care and they all entered foster care at school age (seven or older).

Identity formation was closely linked to the quality of the relationship and two research participants illustrated how they had to juggle loyalties between their birth families and foster families when they got married, with just one inviting her birth parents as well, whereas one who was in a long term relationship had not disclosed to his partner that he was in foster care, suggesting that stigma is associated with the care status rather than the type of placement. 
In terms of young people's strategies in managing their care status, data in this study indicates that many of the research participants in residential and foster care employed passing (hiding their care status from their school peers and others) as a strategy to manage their care status and protect their self-esteem during adolescence. In other cases, different strategies were used at different stages of life switching for example from isolation as a strategy to cope with stigma to self-disclosure where the young person engaged with a small number of peers to whom they disclosed their status. Some of the narratives in residential and foster care, and several narratives in adoption (both domestic and intercountry) did not point out any struggle, suggesting that the young people acted compliantly, either because they were content with their placement or because they did not have the agency to change their situation. Negativism during adolescence appeared as a strategy in some narratives in the intercountry adoption group, for one in the domestic adoption group and for two in the foster care group. As Breakwell (1986) points out, negativism is a double-sided process in which continuity and distinctiveness clash. Indeed, most cases where negativism was adopted as a coping strategy, the placement broke down (four cases in intercountry adoption and two in foster care). In another case the young person moved from compliance in her foster care placement to contesting it, which led to the change of placement to a kinship placement, at the young person's request.

\subsection{Making Sense of Self in Domestic and Intercountry Adoption}

Unlike residential and foster care, children who were adopted had their legal identity changed. They had new birth certificates issued that stated the name of their adoptive parents 
as their parents, and those adopted internationally at an early age had their first names changed as well.

The two sets of narratives (seven life histories of domestic adoption and nine of intercountry adoption) displayed similarities as well as contrasts in identity formation. Findings suggest that the cultural differences contributed to whether, and to the way in which adoption was communicated to them during childhood. As in foster care, the adoptees' relationship with the adoptive parents seemed to have played an important role in their need to gain knowledge of their birth family. The desire to meet their birth family was strongly expressed in cases in which adoptive parents were over restrictive, abusive and where the relationship with the adoptive parents was fraught with conflict.

\subsubsection{Domestic Adoption}

The narratives of the Romanian adoptees confirm a culture of secrecy (Groza, Muntean, $\&$ Ungureanu, 2012) in relation to adoption, with three of the seven adoptees learning from others that they were adopted and one learning from his adoptive mother during a conflict in adolescence. Two of the seven domestic adoptees grew up with the knowledge of being adopted and they both spoke about lengthy periods of time trying to make sense of adoption and struggle to understand what 'real' parents or grandparents would be like. One adoptee (adopted at eight) was in an open adoption arrangement with regular contact with her siblings who stayed at home.

Several adoptees mentioned bullying in primary school either in relation to adoption or ethnicity. As regards the relationship with their parents, the narratives suggest that one of them felt neglected by his adoptive mother, one felt he was emotionally abused by an over- 
controlling adoptive mother and one was physically and emotionally abused throughout her childhood. In the latter case, learning that she was adopted during her teenage years, led to mental health issues (depression and suicidal thoughts) and eventually led to her being listened to and taken by her adoptive parents to meet her birth mother.

In the domestic adoption cluster, four domestic adoptees had met their birth parents by the time of the interview; one was unsure about the search as he felt unwanted whereas the other had attempted to find his birth mother but found the process too onerous. However, when reunions did take place, they were rich descriptions in the young people's narratives. One important finding is the fact that the relationships with the adoptive parents did not change following the reunion with the birth parents. All adoptees in the domestic adoption cluster described highly committed parents and all except one (who moved into residential care at age 16 following adolescence conflicts) had support from their parents in their transition to adulthood. Two research participants described the intense emotional drain of reunion. One of them (who learned in his adulthood that he had been adopted) maintained contact with his birth mother and gave a rich description of his first meeting with his birth mother:

'[W]e met [my birth mother] at a pizza [restaurant] ... [I]t was pretty natural, perhaps also because she is young, she is $37 \ldots$ We were looking at each other and analysing: we both have a space between the front teeth, we both have eyebrows I don't know how... And then we started to discuss, like "what do you do?" and so on. It felt like we hadn't seen each other for a long time and "let's go and have beer and talk" ... What I observed then was that my adoptive mother was afraid as if they were going to take me away... [S] he would say "I did this, I did this" and I was like, "stop justifying yourself, it doesn't matter, let's get over this, it's good we have got to know each other." We speak, I find out things... we speak on Facebook almost every day.' (Male Research Participant, 25)

All research participants in this group went into higher education and all except one were or had been in a stable, long term relationship. The one who one had not been in a long term relationship was the youngest in this cluster (20 at the time of the interview, 
adopted at age three from residential care) and regarded the adoption stigma as a barrier for his romantic life. Despite most of them struggling to come to terms with their adoptee status during teenage years they appeared they appeared to have achieved identity and the conflicts with their adoptive parents (described by three of them) during teenage years were not a barrier in their identity formation.

\subsubsection{Intercountry adoption}

Unlike domestic adoption, all intercountry adoptees grew up with the knowledge that they were adopted. They grew up with their adoptive parents' narratives about Romania and about their adoption. Half of the adoptees in this cluster grew up with narratives of being rescued. None of them was taken to Romania in order to help develop or maintain that element of their identity.

Seven of the intercountry adoptees in the study visited Romania in their adulthood and five of them met their birth families. Two research participants were unsure about contacting their families as they were concerned about the reactions on their side or their parents' side.

For intercountry adoptees, reunions were more complex as in addition to the search for the birth family, they entailed an exploration of the country they were born in, an exploration that was hindered by the fact that with the exception of the one who left the country at 17 , no other adoptees were able to speak the language although a few had made efforts to learn the language.

The country stereotypes they grew up with and the fact they did not develop their identity gradually led to difficulty in understanding their own identity: lack of understanding of the 
context led in some cases to confusion. This is how one adoptee commented on the fact that her brother raised by their birth mother had a Mac when she got in touch with him: 'Those Romanians are supposed to be poor. My brother sends me a picture of a MacBook and I'm like um... [giggles] how did you get that?'

In addition to their name, they lost their citizenship and those who tried to regain it found the process costly and onerous. For most of them, identity formation comprised struggles of belonging with one saying 'I belong to the universe', another stating 'I couldn't feel less American at all. I don't identify with this country ... I just exist', and another one saying 'I am still trying to find myself. I don't even know who I am, a lot of people say I'm charismatic and a social butterfly and very flirtatious and empathetic'. The identity ambivalence is well described by the following quote:

'I'm English, you know... I speak English, I live in England, I have English friends... I don't live in Romania, I don't speak Romanian, I don't know how Romanian people live, you don't know how English people live, you know, it's... But no, there's also, I was born in Romania, I think I have a Romanian way of thinking.'

They kept at least one element of their identity from Romania: their first or both Romanian names, their birth town in their online profile or their connectedness to birth relatives. In this group, only two of the nine research participants were involved in long term romantic relationships at the time of the interview and in both cases their partners were not aware of their adoption history. These interviewees were siblings and although the younger one spent her first five years in residential care and experienced significant emotional abuse in adoption, the very close relationship with her sister who rescued her when she became an adult seems to have mitigated the effects of early age institutionalisation observed in other similar trajectories. Two research participants did not speak about any romantic relationship (both young men encountered trauma during adoption) and another three of the nine research 
participants described past toxic relationships which appears to be connected to low selfesteem or their adoption status. The identity formation in this cluster suggested a lot more struggle, similar to Kroger and Marcia's (2012) description of identity diffusion, possibly explained by the discontinuities they encountered during their care and adoption trajectories.

\subsubsection{Similarities and differences in domestic and intercountry adoption}

While in domestic adoption several adoptees mentioned their struggle to make sense of adoption, comparing their relationships with the adoptive parents to other children's relationships with their 'real' parents, those in intercountry adoption grew up with the knowledge of being adopted and as such adoption was a subject they could discuss openly with their adoptive parents. However, bullying and stigmatisation appeared in both domestic and intercountry adoption, affecting the adoptees' self-esteem and social identity. In contrast to domestic adoptees who were supported by their adoptive families in their transition to adulthood and all went to university, several intercountry adoptees in this study left their adoptive families following conflicts with the adoptive parents and most of them spoke about mental health issues. Only three of the nine were living with their family at age 18 and only one had the support of his family to go to university.

Findings suggest that while all adoptees expressed different levels of interest in knowing their birth parents, for those adopted in Romania, reunion was somewhat facilitated by the understanding of context and not achieving reunion did not prevent adoptees developing educationally and in their professional life. When adolescence conflicts arose, those were overcome and at the time of the interview, all interviewees in the domestic cluster were in contact with their adoptive parents whereas only one third of those in intercountry adoption were in contact with their adoptive parents. 
Contrastingly, for many of the intercountry adoptees reunion was more complex, more difficult to achieve and six of the nine adoptees described low self-esteem and conflict with their adoptive parents during pre-teenage years or adolescence followed by adoption breakdown in one case and loss of contact in the others. Only two of the nine went to university and only one had the support of the adoptive parents to do so. Only one of the nine intercountry adoptees was able to maintain the relationship with his birth mother as she taught him Romanian and he decided to move to Romania. These findings suggest the strong impact of adoption in the young people's development in adulthood.

\section{Discussion of findings}

The use of life history interviews allowed for an understanding of identity formation from the perspective of the young people. All the research participants spoke about how young people were treated by their carers, their peer relationships in and outside care and their knowledge of their birth family and how they managed that.

We explored care from an identity perspective and used Breakwell's conceptualisation of threatened identity to investigate the impact of care on a child's continuity, distinctiveness and self-esteem in different types of placement.

Findings indicate that the type as well as the quality of placement the young people were placed in impacted differently on their identity and on the opportunities they had to manage the disruption introduced when they entered care, on their distinctiveness and self-esteem. 
Sifting the data through identity related concepts such as stigma and relations with others in different types of placement, it appears that the quality of placement impacted of the young person's self-esteem, trust and their romantic relationships (Coll et al., 2010; Orlofsky et al., 1973). Young people that were in placements where they were listened to, were supported to overcome stigma and to re-establish their self-esteem, managed to achieve identity whereas others struggled to make sense of who they were, particularly in intercountry adoption where the struggle was more complex, affecting young people's mental health. For intercountry adoptees, the fact that Romania continued to be presented in international media throughout their childhood as a country failing to protect children (Bejenaru \& Tucker, 2014), and the fact that their adoptive parents' narratives involved elements of corruption in adoption, contributed to a low self - esteem manifested in at least two cases in the adoptees entering abusive relationships.

While most participants in residential care and foster care were supported to meet their birth families, most adoptees did not feel supported by their adoptive parents in getting knowledge of their birth families, with some adoptive parents obstructing access to information.

Contact with the birth family was more difficult in adoption where adoptive parents obstructed access to the adoption papers in many cases. When reunions involved the participation of the birth and the adoptive mother (two cases), the adoptees described states of anxiety particularly on the side of the adoptive parents. However, in none of the cases where adoptees met their birth parents, did the quality of the pre-existing relationship with the adoptive parents change. In foster care, the response offered by foster carers in the young person's interest in their birth family was an important marker of the quality of that placement. Reunion was followed by regular contact in some cases whereas in others, the purpose of the reunion was for the young person to achieve closure. Relationships with 
siblings were in several cases (but not all) more important than relationships with parents. In some instances, siblings were able to offer protection both in and outside care.

The continuity principle was most affected where those adopted had their names, citizenship and linguistic and cultural environment changed, all these adding new layers of complexity during their search for the self during adolescence. During adulthood, some intercountry adoptees chose to replace their full adoptive name with their Romanian one, or to add their Romanian first name to their adoptive first name, either formally or informally, and several were interested in regaining their Romanian citizenship.

Experiences of stigmatisation or fear of stigmatisation and low self-esteem emerged in all types of placement. However, what seemed to have contributed to the young people's development and agency was how they were treated by their carers as well as having some knowledge and understanding of their birth family. Their self-esteem was affected by the quality of the relationships with their main carers and other significant adults that supported their self-esteem rather than the type of placement. This finding has implications in the way care placements for children should be understood since both type of experiences (abuse and individualised, respectful care) were identified across all placement types.

This study suggests that relationships are key to the children in care's identity formation, their agency and self-esteem and for the manner in which they are able to manage their transition to adulthood. As such, service providers should consider the quality of relationship and markers such as stability, belonging, agency, self-esteem as key in providing good quality care where young people aspire and are capable of achieving desirable outcomes for themselves and the society around them. 


\section{Implications for Policy and Practice}

At a time when different schools of thought (rights based, relationship based, social pedagogy or permanency to name a few) are influencing child protection policies in different countries, this study brings valuable insights on what care means to those who experience it. Key learning from this study suggests that:

- Regardless of the type of placement, children in care need to have knowledge of their birth families and their views on this are part of their identity formation. This should be included in training of professionals, carers and adoptive parents. Empathic listening and acting on their views, appears to be an important feature of the quality of the placement. Family type placements (foster care and adoption) can be more challenging contexts in which to express an interest in knowledge of and contact with their birth families.

- Interest in getting to know their families may trigger or be triggered by tension with the foster or adoptive family. This may be caused by over-restrictive or abusive parenting. Children in such circumstances need access to services where they can be listened to and supported.

- Adoptive parents should be supported in managing information and when necessary contact with the birth family and be made aware that relationships with their adopted children are unlikely to be changed after they learn information about their birth family.

- Young people's reports of their experience of contacts suggests that they had the capacity to embrace the knowledge of their birth families as part of their identity and 
that did not damage the quality of the relationship they had established previously with their primary carers.

- Informal contact (without the involvement of the services) arranged by foster carers or adoptive parents was well received by the young people who felt empowered by the continuity created between the different stages of their childhoods.

- Those young people in this study who were not able to gain knowledge or contact their birth families struggled during their adolescence in their identity formation which in some cases affected their mental health significantly.

- For intercountry adoptees, the country of origin is an important element of their identity. They should be supported in maintaining or gaining knowledge of their mother tongue and their country of origin throughout their childhood. Given that citizenship is an important identity element not only legally but also emotionally, children adopted internationally should not be stripped of their native country citizenship.

- Given that stigmatisation was reported in relation to every type of placement, children in care should be supported by carers and professionals in overcoming such experiences. Teachers in particular should be trained in how to support children in care to manage their care status in school.

- Experiences of residential care at an early age appeared to be reflected in experiences of isolation in personal life (no romantic relationships) in adulthood but this was not necessarily the case in adoption. In the intercountry adoption cluster, one research participant was in a long term romantic relationship despite being in residential care since birth (0-9) and despite having experienced persistent abuse in intercountry adoption. Her persistent poor care experiences were mitigated by her encounter with her sister just before she turned 18 who provided her highly intensive, lifesaving 
support. A small number of young people in foster care or intercountry adoption clusters entered toxic relationships at times when they had low self-esteem or lacked of support from their foster carers or adoptive parents as they approached age 18.

This study suggests that identity is an important concept in determining the quality of a placement in children's social care and its quality impacts on young people's self-esteem and agency in adult life. A number of threads identified here such as the connection between quality of placement, identity formation during adolescence and the capability to start healthy romantic relationships in adulthood, deserve further research. 


\section{References}

Agerpres. (2019). Economica.net.

Andersson, G. (2009). Foster Children: a longitudinal study of placements and family relationships. International Journal of Social Welfare, 18, 13-26.

Appiah, K. A. (2005). The Ethics of Identity. Princeton: Princeton University Press.

Bamberg, M. (2015). Who am I? Narrationand Its Contribution to Self and Identity. In B. Gough (Ed.), Qualitative Research in Psychology (pp. 233-257). London, Thousand Oaks, New Dehli, Singapore.

Baumeister, R. (1986). Identity - Cultural Change and the Struggle for Self. New York, Oxford: Oxford University Press.

Bejenaru, A., \& Tucker, S. (2014). Challenging dominant representations of residential childcare in Romania: an exploration of the views of children and young people living in the care system. Journal of Youth Studies, 17(10), 1292-1305. https://doi.org/10.1080/13676261.2014.918250

Bejenaru, A., \& Tucker, S. (2017). Voices of Youth from Romanian Residential Care Homes on Rights and Participation. In P. L. Runcan, G. Rata, \& M. B. Iovu (Eds.), Child and Family Welfare (pp. 95-111). Newcastle upon Tyne: Cambridge Scholars Publishing.

Biehal, N., Ellison, S., Baker, C., \& Sinclair, I. (2010). Belonging and Permanence: Outcomes in long-term foster care and adoption. 809-811. https://doi.org/10.1093/bjsw/bcr087

Boyle, C., \& Boyle, C. (2015). 'What is the impact of birth family contact on children in adoption and long-term foster care?'A systematic review Correspondence : 22-33. https://doi.org/10.1111/cfs.12236

Breakwell, G. (1986). Copying with Threatened Identities. London \& New York: Methuen. Coleman, J. (2011). The Nature of Adolescence (Fourth). East Sussex: Routledge. 
Coll, K. M., Powell, S., Thobro, P., \& Haas, R. (2010). Family Functioning and the Development of Trust and Intimacy Among Adolescents in Residential Treatment. 255262. https://doi.org/10.1177/1066480710372082

Courtney, M. E., Okpych, N. J., Charles, P., Mikell, D., Stevenson, B., Kindle, B., ... Feng, H. (2016). Findings from the California Youth Transitions to Adulthood Study( CalYOUTH ): Conditions of Youth at Age 19. 1-190.

Dickens, J. (2002). The paradox of inter-country adoption: analysing Romania's experience as a sending country. International Journal of Social Welfare, 11(1), 76-83. https://doi.org/10.1111/1468-2397.00198

Erikson, E. (1994). Identity and the Life Cycle. New York and London: W. W. Norton \& Company.

Fargas, M., \& Mc Sherry, D. (2018). Mixed feelings, curiosity, or indifference: Birth family contact and searching for young adults adopted from care and care-leavers. Sixth International Conference on Adoption Research. Montreal.

Ferguson, L. (2016). Could an Increased Focus on Identity Development in the Provision of Children's Services Help Shape Positive Outcomes for Care Leavers A Literature Review. Child Care in Practice, O(0), 1-16.

https://doi.org/10.1080/13575279.2016.1199536

Gavrilovici, O. (2009). Residential Care of Children in Romania. In M. E. Courtney \& D. Iwaniek (Eds.), Residential Care of Children - Comparative Perspectives (pp. 54-71). Oxford: Oxford University Press.

Georgakopoulou, A. (2006). Small and large identities in narrative (inter)action. In A. de Fina, D. Schirffin, \& M. Bamberg (Eds.), Discourse and Identity (pp. 82-102). Cambridge: Cambridge University Press.

Goffman, E. (1990). Stigma - Notes on the Management of Spoiled Identity. London: Penguin 
Books.

Grotevant, H. D., \& Von Korff, L. (2012). Adoptive Identity. In S. J. Schwatrz, K. Luicks, \& V. L. Vignoles (Eds.), Handbook of Identity Theory and Research. New York Heidelberg Dordrecht London: Springer.

Groza, V. (2014). Adoption Policy And Evidence-Based Domestic Adoption Practice : A Comparison Of Romania , Ukraine , India , Guatemala , And Ethiopia. 35(2), 160-171. https://doi.org/10.1002/imhj.

Groza, V., Muntean, A., \& Ungureanu, R. (2012). The adoptive family within the Romanian cultural context: An exploratory study. Adoption Quarterly, 15(1), 1-17. https://doi.org/http://dx.doi.org/10.1080/10926755.2012.661327

Iusmen, I. (2013). The EU and International Adoption from Romania. International Journal of Law, Policy and the Family, 27(1), 1-27. https://doi.org/10.1093/lawfam/ebs015

James, N., \& Busher, H. (2012). Internet Interviewing. In J. Gubrium, J. A. Holstein, A. B. Marvasti, \& K. D. McKinney (Eds.), The SAGE Handbook of Interview Research: The Complexity of the Craft (2012th ed.). Thousand Oaks, California; London: SAGE. Jenkins, R. (2008). Social Identity (Third). London \& New York: Routledge. Jerre, U. (2005). Conflicting Logics? Implementing capacity and EU Adaptation in a Postcommunist Context. Lund: Lund University.

Kligman, G. (1998). The Politics of Duplicity - Controlling Reproduction in Ceausescu's Romania. Berkeley, CA: University of California Press.

Kools, S. M. (1997). Adolescent Identity Development in Foster Care Published by : National Council on Family Relations Stable URL : http://www.jstor.org/stable/585124 Linked references are available on JSTOR for this article : Adolescent Identity Development in Foster Care *. Family Relations, 46(3), 263-271.

Kroger, J., \& Marcia, J. E. (2012). The Identity Statuses: Origins, Meanings and 
Interpretations. In Handbook of Identity Theory and Research (pp. 31-53). New York Heidelberg Dordrecht London: Springer.

Król, M. E., Kliś, A., Kustra, M., \& Szymański, K. (2018). Is knowledge of family history related to psychosocial functioning ? Comparison of adolescents living in institutional care and adolescents living with their biological families. European Journal of Developmental Psychology, 5629, 1-12. https://doi.org/10.1080/17405629.2018.1447460

Licata, L., Margarita, M.-S., \& Green, E. . G. T. (2012). Identity, Immigration and Prejudice in Europe: A Recognition Approach. In S. Schwartz, K. Luyckx, \& V. Vignoles (Eds.), Handbook of Identity Theory and Research. New York Heidelberg Dordrecht London: Springer.

Marcia, J. E. (1980). Identity in Adolescnece. In J. Aldeson (Ed.), The Handbook of Adolescent Psichology (pp. 159-177). New York: John Wiley \& Sons.

McSherry, D., Fargas Malet, M., \& Weatherall, K. (2016). Comparing long-term placements for young children in care: Does placement type really matter? Children and Youth Services Review, 69, 56-66. https://doi.org/10.1016/j.childyouth.2016.07.021

Miles B., M., Huberman A., M., \& Saldana, J. (2014). Qualitative Data Analysis, A Methods Sourcebook (Third). Los Angeles London New Dehli Singapore Washington DC: SAGE.

Noble-carr, D., Barker, J., Mcarthur, M., \& Woodman, E. (2014). Children and Youth Services Review Improving practice : The importance of connections in establishing positive identity and meaning in the lives of vulnerable young people. 47, 389-396. https://doi.org/10.1016/j.childyouth.2014.10.017

Novelle, M. A., \& Gonyea, J. G. (2016). Children and Youth Services Review The availability and role of non-parental identity agents for institutionalized male adolescent social 
orphans in Colombia Child and youth services review. 61, 51-60.

https://doi.org/10.1016/j.childyouth.2015.11.024

Orlofsky, J. L., Marcia, J. E., \& Lesser, I. R. A. M. (1973). EGO IDENTITY STATUS AND THE INTIMACY VERSUS ISOLATION CRISIS OF YOUNG ADULTHOOD. 27(2), 211-219.

Rowe, J., Cain, H., Hundleby, M., \& Keanne, A. (1984). Long-Term Foster Care. London: Batsford Academic and Educational.

Rutter, M., Beckett, C., Castle, J., Colvert, E., Kreppner, J., Mehta, M., ... Sonuga-Barke, E. (2007). Effects of profound early institutional deprivation: An overview of findings from a UK longitudinal study of Romanian adoptees. European Journal of Developmental Psychology, 332-350.

Schofield, G., Larsson, B., \& Ward, E. (2016). Risk, resilience and identity construction in the life narratives of young people leaving residential care. Child and Family Social Work, 1-10. https://doi.org/10.1111/cfs.12295

Schofield, Gillian, Beek, M., \& Ward, E. (2012). Part of the family: Planning for permanence in long-term family foster care. Children and Youth Services Review, 34(1), 244-253. https://doi.org/10.1016/j.childyouth.2011.10.020

Schofield, Gillian, Thoburn, J., Howell, D., \& Dickens, J. (2007). The search for stability and permanence: Modelling the pathways of long-stay looked after children. British Journal of Social Work, 37(4), 619-642. https://doi.org/10.1093/bjsw/bch276

Selwyn, J., \& Wijedasa, D. (2014). Beyond the Adoption Order : challenges, interventions and adoption disruption. (April).

Sen, A. (2006). Identity and Violence. London, New York, Toronto: Penguin Books.

Sharma, S., \& Sharma, M. (2010). Globalization, Threatened Identities, Coping and WellBeing. 55(4), 313-322. https://doi.org/10.1007/s12646-010-0048-8 
Stein, M., Emily, S., \& Munro, R. (2008). Young People's Transitions from Care to Adulthood: International Research and Practice. London: Jessica Kingsley Publishers. Triseliotis, J, \& Hill, M. (1990). Contrasting Adoption, Foster Care and Residential Care. In The Psychology of Adoption. New York; Oxford: Oxford University Press.

Triseliotis, John. (1973). In search of Origins. London and Boston: Routledge\& Kegan Paul. UN General Assembly. (1989). Convention on the Rights of the Child. Treaty Series, vol. 1577, page 3,. https://doi.org/10.2307/4065371

Wijedasa, D., \& Selwyn, J. (2011). Transition to Adulthood for Young People in Adoptive Care: Secondary Analyses of Data from the Longitudinal Study of Young People in England (LSYPE). (September), 1-16.

Winter, K., \& Cohen, O. (2005). Identity issues for looked after children with no knowledge of their origins Implications for research and practice. 29(2). 